\title{
Aleuritopteris punethae (Pteridaceae) a new species of silver fern from Indian Himalaya
}

\author{
B.S.Kholia' ${ }^{1}$ Kamlesh Bhakuni² and R. Punetha ${ }^{2}$
}

\author{
${ }^{1}$ Botanical Survey of India, Sikkim Himalayan Regional Center, Gangtok, Sikkim, India \\ ${ }^{2}$ Department of Botany, P. G. College, Pithoragarh, Uttarakhand, India
}

\begin{abstract}
A new species of Aleuritopteris, A. punethae, is here described from central Himalaya, India. This species has triangular-deltoid lamina similar to those of A. argentea and A. tamburii that also occur in the Himalayan region.
\end{abstract}

\section{Introduction}

Silver or Lip Ferns are widespread in the eastern and western hemispheres and exhibit a wide range of variability in frond morphology. This variability has resulted in as many as nine generic names being applied to them (Copeland 1947, Pichi-Sermolli 1978), in addition to Cheilanthes Sw. However Ching (1941), following Fée (1852), advocated that the Asian species, which differ from the American ones in having golden or white farina and a differently shaped lamina should be transferred to Aleuritopteris Fée. Tagawa (1959), Nayar (1962), Iwastuski (1988) and Kramer and Green (1990) retained the Asian species in Cheilanthes, whereas other authors, including Panigrahi (1960), Saiki (1984a, 1984b, 1984c), Shing \& Wu (1990), Wu (1981), Singh and Panigrahi (2005), Smith et.al. (2006) and Fraser-Jenkins (2008) accept Aleuritopteris as distinct from Cheilanthes. The latter position is supported by the recent molecular studies of Gastony and Rolo $(1995,1998)$ and Schuettpelz et al. (2007).

During the collection of lower vascular plants from some remote areas of the Pithoragarh district, eastern Kumaon (Indian Himalaya), the authors came across a small silver fern (Fig. 1). On the basis of its small fronds with a farinose triangular fertile lamina, it was identified as A. argentea (Gmel.) Kunze (Punetha et al. 2008). Some experts, including Fraser-Jenkins, present at the International Symposium on Perspectives in Pteridophytes held at National Botanical Research Institute, Lucknow (India) in November, 2008 did not accept this assessment. Fraser-Jenkins also encouraged the first author (BSK) to examine the specimens of Aleuritopteris argentea collected from Sikkim by Riboo Rhomoo (Collector of Sir J. D. Hooker) and housed in the herbarium of the Lloyd Botanical Garden, Darjeeling, India (not in Index Herbariorum). On comparison with these specimens and other deltate farinose species in Aleuritopteris sect. Argentae (Ching 1941) from Indian Himalaya, i.e. A. tamburii (Hook.) Ching and A. albomarginata (Clarke) Ching, it was found that the present taxon is distinctively different from them. 
For further confirmation, literature on Cheilanthes Sw. and Aleuritopteris Fée (such as Beddome 1883; Clarke 1880; Hope 1899, 1900; Ching 1935, 1941; Nayar 1962; Wu 1981, 1990; Ching \& Wu 1983; Saiki 1984a; Shing \& Wu 1990; Fraser Jenkins 1997, 2008; Zhang et. al. 2007) from Himalaya and Asia was also consulted but it did not match any species described earlier. A photograph of the plant was also sent to Prof. S. $\mathrm{K}$. Wu ( KUN ) and Prof. X. C. Zhang (Institute of Botany CAS ) for confirmation and comparison with species from China (where most diversity of this genus exists). The critical observations and comments from these Chinese experts, who have extensive knowledge of Aleuritopteris, has encouraged us to describe this plant as a new species.

\section{New Species}

\section{Aleuritopteris punethae Kholia, Bhakuni et R.Punetha sp. nov.}

Cheilanthes argentea sensu Punetha et. al., J. Indian Bot. Soc. 87(3\&4): 289-290, 2008, non (Gmel.) Kunze.

Rhizoma breve erectum apice sparse squamatum; squamae $2 \mathrm{~mm}$ longae nigrae lanceolatae, marginibus integris, apice acuto. Frondes dimorphae; stipites caespitosi castanei foliorum sterilium $6 \mathrm{~cm}$ longi, fertilium $9 \mathrm{~cm}$ longi, basi sparse squamosi supra glabri; squamae ut in rhizomate; laminae subcoriaceae, peltatae, $4.3-4.5 \mathrm{~cm}$ longae pinnatifidae, infra dense vivide albo-farinosae; laminae steriles latiores quam fertiles, pentagonae; laminae fertiles triangulares attenuatae; pinnae laterales 4 vel 5 paribus rhachide adnatae; pinnae basales maiores in laminis sterilibus $2.5 \mathrm{~cm}$ longae, in fertilibus $3 \mathrm{~cm}$, parte basiscopica profunde lobata; pinnae superae gradatim reductae ad rhachim non profunde incisae; lobi lati, marginibus integris apice obtuso; rachis alata; nervi non obscuri; sori marginales secus margines continui; indusia solida; sporae globosae atrofuscae, perinio verrucoso, $40 \times 40 \mu \mathrm{m}$.

Type: India, Himalaya, Pithoragarh, Munsyari, New Lilam in Gori river valley, altitude c. 1800m, September 2006, Kamlesh Bhakuni 307, 24 Sep 2005 (Holotype: BSHC 41337, Isotype: Herb. Bot. Pithoragarh) Fig. 1.

Rhizome short, erect, sparsely scaly at apex; scales $2 \mathrm{~mm}$ long, black, lanceolate, margins entire, apex acute; fronds dimorphic; stipe tufted, chestnut brown, $6 \mathrm{~cm}$ long (in vegetative) $9 \mathrm{~cm}$ long (in fertile), sparsely scaly at base glabrous above; scales as on rhizome; lamina subcoriaceous, peltate, $4.3-4.5 \mathrm{~cm}$ long, 1-pinnatifid; undersurface densely farinose, farina bright white; barren lamina wider than the fertile, pentagonal, fertile lamina triangular, narrowed; lateral pinnae 4 or 5 pairs, adnate to rachis, basal largest, $2.5 \mathrm{~cm}$ long in vegetative lamina, $3.0 \mathrm{~cm}$ in fertile, and deeply lobed on basiscopic side, basal basiscopic pinnules of basal pair of pinnae also adnate laterally at least at base, upper pinnae gradually reduced, not deeply cut to the rachis; lobes broad, margins entire, apex obtuse; rachis winged; veins not obscure, once or twice forked; sori marginal, continuous all along the margins; indusium firm, spores globose, dark brown, perine verrucose, $40 \times 40 \mu \mathrm{m}$.

Habit: lithophyte on rock crevices at semi exposed locality.

Etymology: the species epithet of the plant is named after Dr. N. Punetha, Professor of Botany, Post Graduate College, Pithoragarh, Uttarakhand, India for his outstanding contribution on the morphology of Pteridophytes and pioneering work on the Pteridophyte Taxonomy in Kumaon Himalaya. 


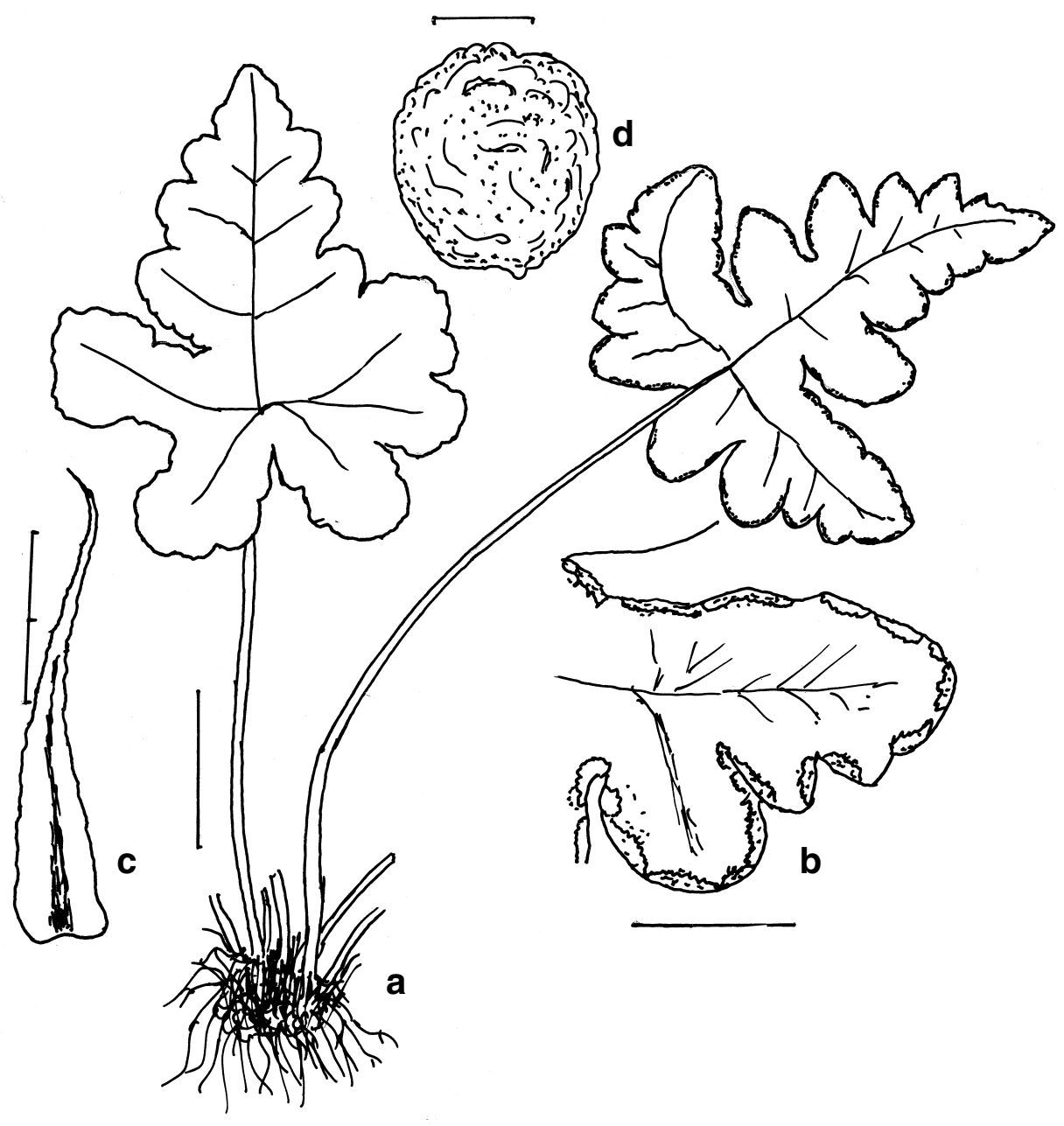

Fig. 1. Aleuritopteris punethae a, habit; b, part of lamina showing indusia; c, rhizome scale; d, spore. 
Distribution: the species is at present known only from the type locality.

The other two species occurring in Indian Himalaya with triangular-deltoid lamina are $A$. argentea and $A$. tamburii but in the former the lamina is distinctly pinnate with 6 or more pairs of lateral pinnae which are distant on the rachis, either pinnatifid or lobed, and only the upper pinnae are adnate to rachis. In A. tamburii the second pair of pinnae is always smaller than the basal and third pairs, often lobed to give a butterfly like appearance, but in A. punethae the lateral pairs of pinnae are fewer in number, gradually reduced and adnate to rachis. They are also jointed to each other and form a regular wing throughout the length of the lamina, so that the rachis is not free. The stipe:lamina ratio is nearly equal in these two species whereas in A. punethae, the stipe is longer than the lamina in fertile fronds. The new species also differs from another Indo Himalayan member of section Argentae (Ching 1941), A. albomarginata, by its smaller size, much more deltate and less dissected lamina, as well as the absence of scales on the costa and costules.

\section{Acknowledgments}

The first author is indebted to C. R. Fraser-Jenkins for his helpful comments and discussion on Aleuritopteris tamburii and A. argentea, and to the staff of the Darjeeling herbarium. The authors are grateful to Prof. S. K. Wu of Kunming Institute of Botany, China (KUN) for examining a photograph and comparing it with Chinese specimens and for his valuable comments; Prof. X. C. Zhang of Institute of Botany, Chinese Academy of Sciences, Beijing, China (PE) for sending Chinese literature, examining a photograph and for his suggestions on an earlier version of the manuscript; Dr. J.-F. Veldkamp of the Nationaal Herbarium, The Netherlands (L), for the Latin description. Dr. M. Sanjappa, Director; Dr. D. K. Singh Additional Director, Botanical Survey of India (BSI), Kolkata and Dr. K. Das, Scientist-in-charge, BSI Sikkim, are also acknowledged for encouragement and providing facilities.

\section{References}

Beddome RH (1883) Handbook to the Ferns of British India: Ceylon and the Malay Peninsula. (Thacker, Spink, and Co., Calcutta with Supplement 1892)

Chandra S, Fraser-Jenkins CR, Kumari A \& Srivastava A (2008) A summary of the status of threatened Pteridophytes of India. Taiwania 53(2): 170-209.

Ching RC (1935) Icones Filicum Sinicarum, vol. 3. (Science Press, Beijing)

Ching RC (1941) The studies of Chinese ferns, Part XXXI. Hong Kong Naturalist 10: 194-204.

Ching RC \& Wu SK (1983) Pteridophyta. Pp. 1-239 in Wu CY (ed.) The series of Scientific expeditions to Qinghi- Xizang platue. Flora Xizangica, vol. 1. (Science Press, Beijing)

Clarke CB (1880) A review of the ferns of Northern India. Transactions of the Linnean Society Series 2. Botany 1: 425-611. (Reprinted in book form by Bishen Singh and Mahendra Pal Singh Dehradun and M/s. Periodical Experts, Delhi India in 1973).

Copeland EB (1947) Genera Filicum. (Cronica Botanica Co., Waltham Massachusetts)

Fée ALA (1850-1852) Genera Filicum. descriptions and figures of the genera of Ferns. (Berger Levrault, Strasburg, Paris)

Fraser-Jenkins CR (1997) New Species Syndrome in Indian Pteridology and ferns of Nepal. (International Book Distributors, Dehradun)

Fraser-Jenkins CR (2008) Taxonomic revision of three hundred Indian subcontinent Pteridophytes. With a revised Census -list, a new picture of fern taxonomy and nomenclature in the Indian subcontinent. (Bishen Singh Mahendra Pal Singh, Dehradun) 
Gastony GJ \& Rollo D (1995) Phylogeny and generic circumscriptions of cheilanthoid ferns (Pteridaceae: Cheilanthoideae) inferred from $r b c \mathrm{~L}$ nucleotide sequences. American Fern Journal 85: 341-360.

Gastony GJ \& Rollo D (1998) Cheilanthoid ferns (Pteridaceae: Cheilanthoideae) in the southwestern United States and adjacent Mexico-a molecular phylogenetic reassessment of generic lines. Aliso 17: 131-144.

Hope CW (1899) The ferns of North-West India. Journal Bombay Natural History Society 12: $527-538$.

Hope CW (1900) The Ferns of North -West India. Journal Bombay Natural History Society 13: $236-251$.

Iwatsuki K (1988) An enumeration of the Pteridophytes of Nepal. Pp. 231-339 in Ohba H \& Malla SB (eds) The Himalayan Plants, vol. 1. (The University Museum, The University of Tokyo)

Kramer KU \& Green PS (1990) Pteridophyta and Gymnosperms. I-XII. Pp. 1-404. in Kubitzki $\mathrm{K}$ (ed.), The Families and Genera of the Vascular Plants, vol. 1. (Springer Verlag, Berlin, Heidelberg, New York)

Nayar BK (1962) Ferns of India-6. Cheilanthes. Bulletin National Botanic Gardens Lucknow 68: $1-36$.

Panigrahi G (1960) A note on Aleuritopteris grisea (Blanf.) Panigrahi, comb. nov and A. anceps (Blanf.) Panigrahi comb. nov. Bulletin of the Botanical Survey of India 2: 321-322.

Pichi-Sermolli REG (1978) Tentamen Pteridophytorum ordinem redigendi. Webbia 31: 313-512.

Punetha N, Bhakuni K \& Kholia B S (2008) On the occurrence of Cheilanthes argentea (a silver fern) in central Himalaya. Journal of the Indian Botanical Society 87: 289-290.

Saiki Y (1984a) Notes on ferns 2. Asiatic species of the Aleuritopteris farinosa complex. Journal of Phytogeography and Taxonomy. 32: 1-13.

Saiki Y (1984b) Notes on Ferns 3. African and Neotropical species of the Aleuritopteris farinosa group. Journal of Phytogeography and Taxonomy. 32: 81-90.

Saiki Y (1984c) Notes on ferns 4. Classification to the Aleuritopteris farinosa group . Journal of Phytogeography and Taxonomy 32: 91-98.

Schuettpelz E, Schneider H, Huiet L, Michael D. Windham \& Pryer KM (2007) A molecular phylogeny of the fern family Pteridaceae: Assessing overall relationships and the affinities of previously unsampled genera. Molecular Phylogenetics and Evolution 44: 1172-1185.

Shing KH \& Wu SK (1990) Sinopteridaceae. Pp.97-173 in Ching RC \& Shing KH (eds) Flora Reipublicae Popularis Sinicae, vol. 3. (Science Press, Beijing)

Singh S \& Panigrahi G (2005) Fern and Fern allies of Arunachal Pradesh, vols 1 \& 2. (Bishen Singh Mahendra Pal Singh, Dehradun. India)

Smith AR, Pryer KM, Schuettpelz E, Korall P, Schneider H \& Wolf PG (2006) A classification for extant ferns. Taxon 55 (3): 705-731.

Tagawa M (1959) Coloured Illustrations of the Japanese Pteridophytes. (Hoikusha Publ. Co. Ltd, Osaka)

Wu SK (1981) A study of the genus Aleuritopteris Fée in China. Acta Phytotaxonomica Sinica 19: $57-74$.

Wu SK (1990) Aleuritopteris Fée. In Ching RC \& Shing KH Flora Reipublicae Popularis Sinicae 3(1): 141-166. (Science Press, Beijing)

Zhang G-M, Yang WL \& Zhang XC (2007) The identity of Aleuritopteris veitchii and A.duclouxii var. sulphurea in Sinopteridaceae. Acta Phytotaxonomica Sinica 45 (3): 359-362.

Manuscript received 30 July 2009, accepted 31 March 2010 